\title{
Klasifikasi Jenis Golongan Darah MenggunakanFuzzy C-Means Clustering (FCM) dan Learning Vector Quantization (LVQ)
}

\author{
Fajar Rohman Hariri, Danar Putra Pamungkas
}

\begin{abstract}
Blood is an important part of the body. Blood is divided into several groups $\mathrm{A}, \mathrm{B}, \mathrm{O}$, and $\mathrm{AB}$. Conventionally, detect blood group by dripping anti-A serum and anti-B serum into the blood to be recognized and direct measurement of the serum droplet reaction. This study will compare the processes that use segmentation and without using segmentation to know the various segmentation information in introduction of human blood type image. From the test results that segmentation increase accuracy of recognition between $10 \%-24 \%$ of each test. By using JST Learning Vector Quantization (LVQ) as a classifier and Fuzzy C-Mean as segmentation, the optimal result on the system averages $92 \%$ to $98 \%$.
\end{abstract}

\section{Index Terms-Blood, Segmentation, Classification}

Abstrak-- Darah merupakan salah satu bagian penting dalam tubuh. Darah dibedakan menjadi beberapa golongan yaitu A, B, O, dan AB. Secara konvensional, mendeteksi golongan darah dengan cara meneteskan serum anti-A dan serum anti-B ke darah yang akan dikenali kemudian melakukan pengamatan langsung terhadap reaksi tetesan serum tersebut. Penelitian ini akan membandingkan antara proses pengenalan yang menggunakan segmentasi dengan proses pengenalan tanpa menggunakan segmentasi untuk mengetahui seberapa besar pengaruh metode segmentasi dalam pengenalan citra golongan darah manusia. Dari hasil pengujian didapatkan bahwa dengan adanya metode segmentasi akurasi system pengenalan bertambah antara $10 \%-24 \%$ setiap uji coba. Dengan menggunakan JST Learning Vector Quantization (LVQ) sebagai pengklasifikasi dan Fuzzy C-Mean sebagai segmentasi citra darah dapat diperoleh hasil yang optimal pada sistem pengenala golongan darah manusia dengan prosentase keberhasilan rata rata $92 \%$ hingga $98 \%$.

Kata Kunci-Darah, Segmentasi, Klasifikasi

\section{PENDAHULUAN}

P engolahan citra merupakan suatu proses yang dilakukan dengan masukan berupa citra dan hasilnya juga berupa citra [1]. Citra adalah gambar

Fajar Rohman Hariri, Teknik Informatika, Universitas Nusantara PGRI Kediri, dosendeso@gmail.com

Danar Putra Pamungkas, Teknik Informatika, Universitas Nusantara PGRI Kediri, danar.aflach@gmail.com pada dua dimensi [2]. Pengolahan citra pada awalnya dilakukan untuk memperbaiki kualitas citra, tetapi dengan berkembangnya dunia komputasi yang ditandai dengan semakin meningkatnya kapasitas dan kecepatan proses komputer, serta munculnya ilmu-ilmu komputasi yang memungkinkan manusia dapat mengambil informasi dari suatu citra, maka pengolahan citra tidak dapat dilepaskan dengan bidang computer vision [3].

Pengolahan citra dan computer vision dalam perkembangan lebih lanjut digunakan sebagai pengganti mata manusia, dengan perangkat penangkap citra seperti kamera dan pemindai (scanner) dijadikan sebagai mata dan mesin komputer dijadikan sebagai otak yang mengolah informasi [4].

Darah merupakan salah satu bagian penting dalam tubuh. Darah dibedakan menjadi beberapa golongan yaitu A, B, O, dan AB. Secara konvensional, mendeteksi golongan darah dengan cara meneteskan serum anti-A dan serum anti-B ke darah yang akan dikenali kemudian melakukan pengamatan langsung terhadap reaksi tetesan serum tersebut. Sistem penggolongan darah ini dimaksudkan untuk mencegah terjadinya reaksi transfuse (hemolysis dan aglutinasi) ketika dilakukan transfusi darah antara donor dan resipen.[5]

\section{LANDASAN TEORI}

\section{A. Sistem Golongan Darah ABO}

Sistem golongan darah ABO dipengaruhi oleh aglutinogen A dan aglutinogen B. Antigen ini ditemukan dalam banyak jaringan selain darah, antara lain kelenjar ludah, saliva, pankreas, ginjal, hati, paru, testes, semen, dan cairan amnion. Antigen A dan B sebenarnya merupakan oligosakarida kompleks yang berbeda gula terminalnya. Pada sel darah merah, antigen ini kebanyakan adalah glikofingolipid, sedangkan di jaringan yang lain adalah glikoprotein. Aglutinin anti A akan terbentuk sebagai antibodi dalam plasma apabila aglutinogen tipe A tidak terdapat dalam sel darah merah manusia. Antibodi yang dikenal sebagai aglutinin anti B akan terbentuk dalam plasma jika tidak terdapat aglutinogen tipe B dalam sel darah merah. Aglutinogen A dan B diturunkan 
secara dominan menurut Mendel dan manusia dibagi menjadi empat golongan darah utama atas dasar ini. Golongan darah ABO diklasifikasikan menurut adanya aglutinogen A dan aglutinogen B seperti pada tabel 1 dibawah ini[6].

Tabel 1. Klasifikasi Sistem Golongan Darah ABO

\begin{tabular}{cccc}
\hline \hline GENOTIP & $\begin{array}{c}\text { GOLONGAN } \\
\text { DARAH }\end{array}$ & AGLUTINOGEN & AGLUTININ \\
\hline $\mathrm{O}$ & $\mathrm{O}$ & Tidak Punya & Anti-A dan \\
& & & Anti B \\
$\mathrm{OA} / \mathrm{AA}$ & $\mathrm{A}$ & $\mathrm{A}$ & Anti-B \\
$\mathrm{AB} / \mathrm{BB}$ & $\mathrm{B}$ & $\mathrm{B}$ & Anti-A \\
$\mathrm{AB}$ & $\mathrm{AB}$ & A DAN B & Tidak Punya \\
\hline \hline
\end{tabular}

\section{B. Fuzzy C-Means Clustering}

Fuzzy C-means Clustering (FCM), atau dikenal juga sebagai FuzzyISODATA, merupakan salah satu metode clustering yang merupakan bagian dari metode Hard K-Means. FCM menggunakan model pengelompokan fuzzy sehingga data dapat menjadi anggota dari semua kelas atau cluster terbentuk dengan derajat atau tingkat keanggotaan yang berbeda antara 0 hingga 1.Tingkat keberadaan data dalam suatu kelas atau cluster ditentukanoleh derajat keanggotaannya. Teknik ini pertama kali diperkenalkan oleh Jim Bezdek pada tahun 1981[7].

Teknik Fuzzy C- Means Clustering juga dapat dipergunakan untuksegmentasi pada suatu citra. Segmentasi bertujuan untuk membagiwilayah-wilayah yang homogen. Segmentasi adalah salah satu metode penting yang digunakan untuk mengubah citra input ke dalam citra outputberdasarkan atribut yang diambil dari citra tersebut.

Konsep dasar FCM, pertama kali adalah menentukan pusat cluster, yang akan menandai lokasi rata - rata untuk tiap - tiap cluster. Pada kondisi awal, pusat cluster ini masih belum akurat. Tiap - tiap titik data secaraberulang, maka akan dapat dilihat bahwa pusat cluster akan bergerakmenuju lokasi yang tepat. Perulangan ini didasarkan pada minimisasi fungsi objektif yang menggambarkan jarak dari titik data yang diberikan ke pusat cluster yang terbobot oleh derajat keanggotaan titik data tersebut[8]

\section{Learning Vector Quantization}

Jaringan saraf tiruan Learning Vector Quantization (LVQ) telah banyak dimanfaatkan untuk pengenalan pola baik berupa citra, suara, dan lain-lain. Jaringan LVQ sering pula digunakan untuk ekstraksi ciri (feature) pada proses awal pengenalan pola. Metode Jaringan Syaraf LVQ termasuk dengan Supervised Learning dalam penentuan bobot / model pembelajarannya, dimana pada metode LVQ ditentukan hasil seperti apa selama proses pembelajaran. Selama proses pembelajaran nilai bobot disusun dalam suatu range tertentu tergantung pada nilai input yang diberikan. Tujuan pembelajaran ini adalah pengelompokan unit-unit yang hampir sama dalam satu area tertentu. Pembelajaran seperti ini sangat cocok untuk pengelompokan (klasifikasi) pola.

Prinsip kerja dari algoritma LVQ adalah pengurangan node-node tetangganya (neighbour), sehingga pada akhirnya hanya ada satu node output yang terpilih (winner node). Pertama kali yang dilakukan adalah melakukan inisialisasi bobot untuk tiap-tiap class. Setelah diberikan bobot, maka jaringan diberi input sejumlah dimensi node/neuron input. Setelah input diterima jaringan, maka jaringan mulai melakukan perhitungan jarak vektor yang didapatkan dengan menjumlah selisih/jarak antara vektor input dengan vektor bobot menggunakan Euclidean distance. Secara matematis Ecluidean Distance dapat dirumuskan[8] :

$$
d_{j}^{2}=\sum_{i=0}^{n-1}\left(X_{1}(t)-W_{\mathrm{ij}}(t)\right)^{2}
$$

dimana :

$$
\begin{aligned}
& d_{j}^{2}=\text { distance } \\
& X_{t}=\text { Node data input } \\
& W_{i j}=\text { Bobot ke-ij }
\end{aligned}
$$

Setelah diketahui tiap-tiap jarak antara nodeoutput dengan input maka dilakukan perhitungan jumlah jarak selisih minimum. Dimana node yang terpilih (winner) berjarak minimum akan di update bobot, update bobot node winner yang dirumuskan sebagai berikut:

Jika sesuai target memakai rumus:

$$
\begin{gathered}
w_{\mathrm{ij}}(t+1)=w_{\mathrm{ij}}(t)+\alpha(t) \cdot\left(x_{i}(t)-w_{\mathrm{ij}}(t)\right), j \in N_{e} \\
\text { dan jika tidak } \\
w_{\mathrm{ij}}(t+1)=w_{\mathrm{ij}}(t)-\alpha(t) \cdot\left(x_{i}(t)-w_{\mathrm{ij}}(t)\right), j \in N_{e} \\
0<\alpha(t)<1
\end{gathered}
$$

dimana :

$$
\begin{aligned}
\mathrm{x} & =\text { Input pixel } \\
\mathrm{w} & =\text { bobot } \\
\mathrm{Ne} & =\text { Nilai neighborhood } \\
\mathrm{t} & =\text { waktu } \\
\mathrm{i} & =\text { index node input } \\
\mathrm{j} & =\text { index node output } \\
\alpha & =\text { alpha learning rate }
\end{aligned}
$$

$\alpha(\mathrm{t})$ merupakan alpha/learning rate yaitu faktor pengali pada perubahan bobot yang berubah terhadap perubahan error. Perubahan alpha ini sesuai dengan banyaknya input yang masuk. Faktor pengali alphallearningrate ini akan selalu berkurang bila tidak ada perubahan error. Dalam penelitian ini alphalearningrate akan berubah berkurang secara geometris sebagai berikut :

$$
\alpha(\mathrm{t}+1)=0.1 * \alpha(\mathrm{t})
$$

Secara garis besar algoritma Learning Vector Quantization $(L V Q)$ sebagai berikut[8]:

1. Siapkan data learning, $x(m, n)$ dan target $T(1, n)$.

2. Inisialisasi bobot (W), maksimum epoh (Max Epoh), error minimum yang diharapkan (Eps), learning rate $(\alpha)$. Max Epoh dan learning rate digunakan untuk menentukan batas ambang komputasi.

3. Melakukan proses sebagai berikut selama (epoh $<$ makEpoh) atau ( $\alpha>$ eps).

- $\quad$ epoh $=$ epoh+1. 
- Kerjakan untuk i=1 sampai $n$.

- Tentukan $\mathrm{j}$ sedemikian rupa sehingga $\left\|\mathrm{X}-\mathrm{W}_{\mathrm{j}}\right\|$ minimum (Sebut sebagai $\mathrm{C}_{\mathrm{j}}$ )

- Perbaiki $\mathrm{W}_{\mathrm{j}}$ dengan ketentuan

- Jika $\mathrm{T}=\mathrm{C}_{\mathrm{j}}$ maka : $\mathrm{W}_{\mathrm{j}}($ baru $)=\mathrm{W}_{\mathrm{j}}($ lama $)+\alpha\left(\mathrm{X}-\mathrm{W}_{\mathrm{j}}(\right.$ lama $\left.)\right)$

○ Jika $\mathrm{T} \neq \mathrm{C}_{\mathrm{j}}$ maka :

$\mathrm{W}_{\mathrm{j}}($ baru $)=\mathrm{W}_{\mathrm{j}}($ lama $)-\alpha\left(\mathrm{X}-\mathrm{W}_{\mathrm{j}}(\right.$ lama $\left.)\right)$

- Kurangi nilai $\alpha$

4. Kembali ke langkah ke-3, jika (epoh<makEpoh) atau ( $\alpha>$ eps) tidak terpenuhi, selesai.

Setelah dilakukan pelatihan, akan diperoleh bobot akhir (W). Bobot-bobot ini nantinya akan digunakan untuk melakukan klasifikasi terhadap data baru.

Gambar 1 berikut merupakan flowchart LVQ

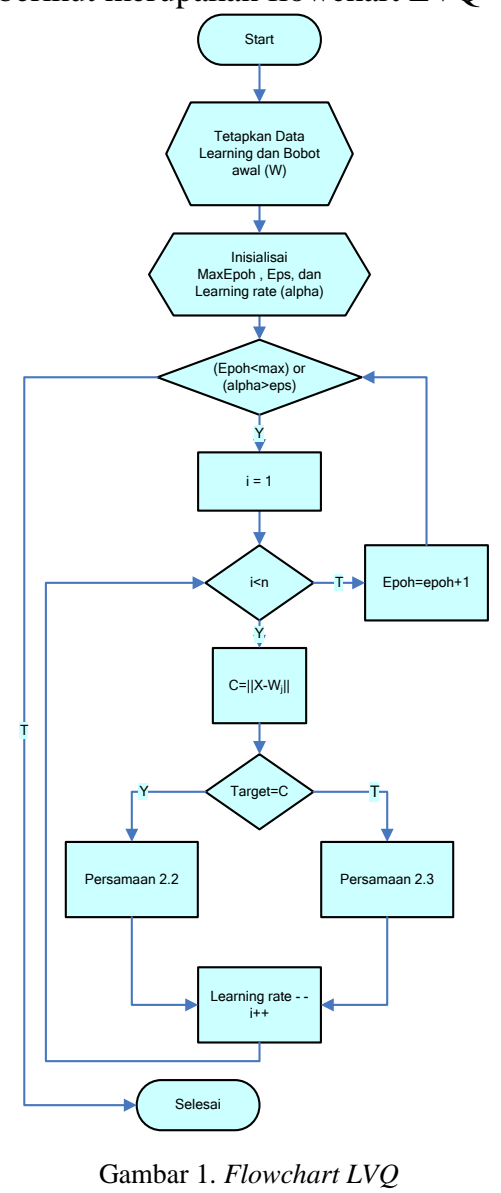

\section{METODE PENELITIAN}

Penelitian ini merupakan penelitian eksperimental, karena untuk mendapatkan performa terbaik algortima LVQ dalam mengklasifikasikan, dilakukan beberapa kali percobaan dengan parameter yang berbeda-beda.

\section{HASIL PENELITIAN}

Penelitian ini menggunakan data untuk proses pengujian citra terdiri dari 4 golongan darah, golongan darah yang digunakan untuk keperluan pengenalan sebanyak 100 citra dengan masing masing citra terdiri dari 4 tetes darah,sedangkan citra pelatihan adalah 200 citra sengan masing masing citrahanya terdiri dari 1 tetesan darah.
Dilakukan ujicoba tanpa segmentasi menghasilkan akurasi sesuai tabel 2 berikut

Tabel 2. Akurasi tanpa segementasi Citra Pelatihan

\begin{tabular}{cccc} 
Coba & Menggumpal & $\begin{array}{c}\text { Tidak } \\
\text { menggumpal }\end{array}$ & akurasi \\
\hline 100 & 5 & 5 & $66 \%$ \\
100 & 5 & 5 & $66 \%$ \\
100 & 5 & 5 & $66 \%$ \\
100 & 5 & 5 & $64 \%$ \\
100 & 5 & 5 & $66 \%$
\end{tabular}

$100 \quad 5 \quad 5 \quad 65 \%$

$\begin{array}{llll}100 & 5 & 5 & 66 \% \\ 100 & 5 & 5 & 66 \%\end{array}$

$100 \quad 5$

100

100

100

100

100

100

100

100

100

100

100

100

100

100

100

100

100

100

100

100

100

100

100

100

100

100

100

100

100

100

100

100

100

100

100

100

100

100

100

100

100

100

100

100

100

100

100

100

100

100

100

100

100

100

100

100

100

100

100

100

100

$66 \%$
$66 \%$

$66 \%$

$73 \%$

$73 \%$

$72 \%$

$73 \%$

$73 \%$

$73 \%$

$73 \%$

$72 \%$

$73 \%$

$73 \%$

$75 \%$

$75 \%$

$75 \%$

$75 \%$

$74 \%$

$75 \%$

$75 \%$

$75 \%$

$75 \%$

$75 \%$

$81 \%$

$81 \%$

$81 \%$

$80 \%$

$81 \%$

$81 \%$

$81 \%$

$81 \%$

$81 \%$

$81 \%$

$81 \%$

$81 \%$

$81 \%$

$81 \%$

$81 \%$

$81 \%$

$81 \%$

$80 \%$

$81 \%$

$81 \%$

$81 \%$

$81 \%$

$81 \%$

$81 \%$

$81 \%$

$81 \%$

$81 \%$

$80 \%$

$84 \%$

$83 \%$

$84 \%$

$84 \%$

$84 \%$

$84 \%$

$84 \%$

$84 \%$

$84 \%$

$84 \%$

$84 \%$ 
Selanjutnya dilakukan ujicoba dengan menggunakan segmentasi menghasilkan akurasi sesuai tabel 3 berikut

Tabel 3. Akurasi dengan segementasi FCM

\begin{tabular}{|c|c|c|c|}
\hline \multirow[b]{2}{*}{$\begin{array}{c}\text { Citra Uji } \\
\text { Coba }\end{array}$} & \multicolumn{2}{|c|}{ Citra Pelatihan } & \multirow[b]{2}{*}{ akurasi } \\
\hline & Menggumpal & $\begin{array}{c}\text { Tidak } \\
\text { menggumpal }\end{array}$ & \\
\hline 100 & 5 & 5 & $76 \%$ \\
\hline 100 & 5 & 5 & $76 \%$ \\
\hline 100 & 5 & 5 & $76 \%$ \\
\hline 100 & 5 & 5 & $76 \%$ \\
\hline 100 & 5 & 5 & $76 \%$ \\
\hline 100 & 5 & 5 & $76 \%$ \\
\hline 100 & 5 & 5 & $76 \%$ \\
\hline 100 & 5 & 5 & $77 \%$ \\
\hline 100 & 5 & 5 & $76 \%$ \\
\hline 100 & 5 & 5 & $76 \%$ \\
\hline 100 & 10 & 10 & $82 \%$ \\
\hline 100 & 10 & 10 & $84 \%$ \\
\hline 100 & 10 & 10 & $84 \%$ \\
\hline 100 & 10 & 10 & $84 \%$ \\
\hline 100 & 10 & 10 & $84 \%$ \\
\hline 100 & 10 & 10 & $84 \%$ \\
\hline 100 & 10 & 10 & $86 \%$ \\
\hline 100 & 10 & 10 & $84 \%$ \\
\hline 100 & 10 & 10 & $84 \%$ \\
\hline 100 & 10 & 10 & $84 \%$ \\
\hline 100 & 30 & 30 & $92 \%$ \\
\hline 100 & 30 & 30 & $92 \%$ \\
\hline 100 & 30 & 30 & $92 \%$ \\
\hline 100 & 30 & 30 & $92 \%$ \\
\hline 100 & 30 & 30 & $92 \%$ \\
\hline 100 & 30 & 30 & $92 \%$ \\
\hline 100 & 30 & 30 & $92 \%$ \\
\hline 100 & 30 & 30 & $92 \%$ \\
\hline 100 & 30 & 30 & $92 \%$ \\
\hline 100 & 30 & 30 & $92 \%$ \\
\hline 100 & 50 & 50 & $95 \%$ \\
\hline 100 & 50 & 50 & $95 \%$ \\
\hline 100 & 50 & 50 & $95 \%$ \\
\hline 100 & 50 & 50 & $95 \%$ \\
\hline 100 & 50 & 50 & $95 \%$ \\
\hline 100 & 50 & 50 & $95 \%$ \\
\hline 100 & 50 & 50 & $95 \%$ \\
\hline 100 & 50 & 50 & $94 \%$ \\
\hline 100 & 50 & 50 & $93 \%$ \\
\hline 100 & 50 & 50 & $95 \%$ \\
\hline 100 & 60 & 60 & $95 \%$ \\
\hline 100 & 60 & 60 & $95 \%$ \\
\hline 100 & 60 & 60 & $95 \%$ \\
\hline 100 & 60 & 60 & $94 \%$ \\
\hline 100 & 60 & 60 & $95 \%$ \\
\hline 100 & 60 & 60 & $95 \%$ \\
\hline 100 & 60 & 60 & $95 \%$ \\
\hline 100 & 60 & 60 & $95 \%$ \\
\hline 100 & 60 & 60 & $95 \%$ \\
\hline 100 & 60 & 60 & $95 \%$ \\
\hline 100 & 70 & 70 & $96 \%$ \\
\hline 100 & 70 & 70 & $96 \%$ \\
\hline 100 & 70 & 70 & $96 \%$ \\
\hline 100 & 70 & 70 & $96 \%$ \\
\hline 100 & 70 & 70 & $96 \%$ \\
\hline 100 & 70 & 70 & $95 \%$ \\
\hline 100 & 70 & 70 & $96 \%$ \\
\hline 100 & 70 & 70 & $96 \%$ \\
\hline 100 & 70 & 70 & $96 \%$ \\
\hline 100 & 70 & 70 & $96 \%$ \\
\hline 100 & 80 & 80 & $98 \%$ \\
\hline 100 & 80 & 80 & $98 \%$ \\
\hline 100 & 80 & 80 & $98 \%$ \\
\hline 100 & 80 & 80 & $98 \%$ \\
\hline 100 & 80 & 80 & $98 \%$ \\
\hline 100 & 80 & 80 & $98 \%$ \\
\hline 100 & 80 & 80 & $98 \%$ \\
\hline 100 & 80 & 80 & $98 \%$ \\
\hline 100 & 80 & 80 & $98 \%$ \\
\hline 100 & 80 & 80 & $98 \%$ \\
\hline
\end{tabular}

Perbedaan akurasi pengenalan menggunakan $F U Z Z Y$ CMEAN dan tanpa menggunakan FUZZY C-MEAN ditunjukkan oleh tabel 4 dan gambar 2 berikut

Tabel 4. Perbedaan Akurasi

\begin{tabular}{rrrr}
\hline \multirow{2}{*}{$\begin{array}{c}\text { Jumlah } \\
\text { Citra Uji }\end{array}$} & $\begin{array}{c}\text { Jumlah Citra } \\
\text { Pelatihan }\end{array}$ & \multicolumn{2}{c}{ Rata - ratu akurasi } \\
\cline { 3 - 4 } & 10 & $66 \%$ & $\begin{array}{c}\text { Tengan } \\
\text { segmentasi }\end{array}$ \\
100 & 20 & $73 \%$ & $76 \%$ \\
100 & 60 & $75 \%$ & $94 \%$ \\
100 & 100 & $81 \%$ & $95 \%$ \\
100 & 120 & $81 \%$ & $95 \%$ \\
100 & 140 & $81 \%$ & $96 \%$ \\
100 & 160 & $84 \%$ & $97 \%$ \\
100 & 180 & $84 \%$ & $97 \%$ \\
100 & 200 & $84 \%$ & $98 \%$ \\
\hline \hline
\end{tabular}

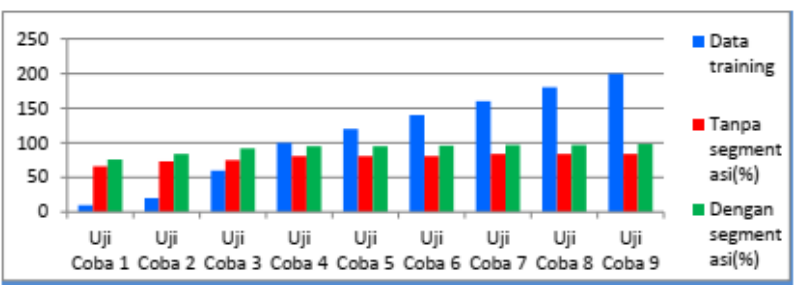

Gambar 2. Grafik Perbedaan Akurasi

\section{KESIMPULAN}

Dari hasil percobaan dapat diketahui bahwa aplikasi pengenalan golongan darah manusia pada citra digital dengan menggunakan metode Fuzzy C-Mean sebagai metode segmentasi dan Learning Vector Quantization sebagai metodel klasifikasi dapat diaplikasikan dengan baikpada proses pengenalan golongan darah manusia. Penggabungan metode ini sangat baik pada proses pengenalan, dari hasil uji coba yang melibatkan 200 citra pelatihan dan 100 citra uji coba didapatkan hasil akurasi yang tinggi, yakni rata rata antara 92\% sampai 98\% tingkat keberhasilan.

\section{REFERENCES}

[1] Efendy, Bobby. 2009. Autentifikasi Telapak Tangan pada Citra Digital Menggunakan Metode Support Vector Machine (SVM). Madura: Skripsi Universitas Trunojoyo.

[2] Adiyat, Iqbal. 2013. Aplikasi Pengolahan Citra Digital Berbasis Flash pada Perangkat Mobile. Pontianak: Universitas Tanjungpura.

[3] Mulyawan, Hendy, Samsono, Hadi, Setiawardhana. 2011. Identifikasi dan Tracking Objek Berbasis Image Processing secara Real Time. Surabaya: Institut Teknologi Sepuluh.

[4] Mughni, Ilham, Somantri, Maman, Isnanto, Rizal. 2012. Sistem Identifikasi Berdasarkan Ciri Garis- Garis Utama Telapak Tangan Menggunakan Metode Overlapping Block. Semarang: Universitas Diponegoro.

[5] L. Sherwood, Fisiologi Manusia : dari Sel ke Sistem. Terjemahan Nella Yesdelita. Jakarta: EGC. 2011.

[6] Guyton, A. C., 1996.Buku Ajar Fisiologi Kedokteran (Textbook of Medical Physiology) Edisi 8 dan 10, Jakarta: Penerbit Buku Kedokteran EGC

[7] Kusumadewi, S. 2004. Membangun Jaringan Syaraf Tiruan menggunakan Matlab dan Excel Link.Yogyakarta:Graha Ilmu.

[8] Kusumadewi, S. 2003. Artificial Intelligence (Teknik dan Aplikasinya). Yogyakarta:Graha Ilmu. 